\title{
Faces from the Franklin expedition? Craniofacial reconstructions of two members of the 1845 northwest passage expedition
}

\author{
Douglas R. Stenton \\ Department of Culture and Heritage, Government of Nunavut, P.O. Box 1000, Station 800, \\ Iqaluit, Nunavut X0A 0H0, Canada (dstenton1 @ gov.nu.ca)
}

\section{Anne Keenleyside}

Department of Anthropology, Trent University, 2140 East Bank Drive, Peterborough, Ontario

K9J 7B8, Canada

\section{Diana P. Trepkov}

Forensic Artist, 314 Harwood Ave South, P.O. Box 21064 RPO, Harwood Place, Ajax, Ontario L1S 7H2, Canada

\author{
Robert W. Park \\ Department of Anthropology, University of Waterloo, Waterloo, Ontario N2L 3G1, Canada
}

Received December 2014 ; first published online 28 May 2015

\begin{abstract}
In 2013, partial skeletal remains from three members of the 1845 John Franklin expedition were recovered from an archaeological site at Erebus Bay, King William Island, Nunavut. The remains included three crania, two of which were sufficiently intact to allow craniofacial reconstructions. Identifications are not proposed for either reconstruction; however, tentative identifications are being explored through DNA analyses currently underway that include samples obtained from both crania.
\end{abstract}

\section{Introduction}

On 22 April 1848, the 105 surviving members of the 1845 northwest passage expedition led by Sir John Franklin abandoned HMS Erebus and HMS Terror, which had been beset in ice northwest of King William Island since September 1846. Over a three-day period they hauled an enormous quantity of supplies and equipment across 25 kilometres of ice in Victoria Strait to the northwest shore of King William Island. After establishing a temporary camp near Victory Point, on 26 April 1848, they commenced what proved to be a disastrous march southward along hundreds of kilometres of coastline en route to the Back River and, hopefully, to their salvation. None of the men survived; over the subsequent 166 years the remains of approximately one-third of their number have been discovered but of these, very few have been identified.

Of the remains discovered through search and rescue efforts between 1850 and 1880 (for example Cyriax 1939; Ross 2002) only six individuals have been positively or tentatively identified. Of these, three (John Torrington, William Braine and John Hartnell) died during the first winter of the expedition (between January and April 1846) and were buried on Beechey Island in 1846 (Beattie and Geiger 1987). Subsequently, as revealed in a cairn record discovered in 1859 at Victory Point on King William Island where the men had briefly encamped, an additional 21 men perished in the 24 months that preceded the abandonment of HMS Erebus and HMS Terror in 1848, including Sir John Franklin and Lieutenant Graham Gore (McClintock 1860: 258-259). The identities of the other nineteen fatalities are unknown as is the manner in which they were buried.

The remaining 105 men died during the journey to the Back River, and some of their skeletal remains have been discovered at several points along the path of the southward retreat. The first to be found were the partial remains of two men in a ship's boat at Erebus Bay in 1859 (McClintock 1860; Hobson 1859; Stenton 2014), and a few years later Inuit reported seeing a large number of human bones in a second ship's boat located nearby, as well as at expedition camps at Terror Bay and at Starvation Cove (for example Hall 1869; Stackpole 1965). In other locations, smaller quantities of bones were found scattered over the surface of the ground and, in some cases, in or near disturbed stone graves (Klutschak 1987; Stackpole 1965: 87; Gilder 1881: 289).

The exact number of bones of members of the Franklin expedition found by nineteenth-century searchers along the route of the retreat is unknown; however, in all but two cases, the remains were not collected. Instead, they were buried (or reburied) or simply left as they were found. Decisions to bury rather than to collect the remains appear to have been based on the low probability of their future identification. In some cases, the quality of remnants of clothing or other materials and objects associated with remains (for example watches, silverware engraved with family crests) suggested that they might have been those of officers, but there were very few clues that would otherwise aid the identification of any of the individuals. The ability to identify remains was evidently 
the sole collection criterion used by Frederick Schwatka who, despite having received instructions to recover all Franklin expedition human remains that he might find, buried all of the bones that he found except for those of Lieutenant John Irving (Gilder 1881: 5). In other cases, such as the two discrete sets of skeletal remains found in a boat in Erebus Bay by the McClintock expedition, no explanation was given for apparently leaving the bones as and where they had been found (McClintock 1860: 271).

Identifications have been made for just three sets of remains, of which only two were collected. In 1859, McClintock found near Cape Herschel, on the south coast of King William Island, a partial skeleton and some personal effects, including a pocketbook containing a seaman's certificate that suggested the remains were those of Petty Officer Henry ('Harry') Peter Peglar of HMS Terror (McClintock 1860: 248). McClintock collected many of the personal effects found with the skeleton, but not the bones.

In 1869, Charles Francis Hall collected and conveyed to England the remains of an individual discovered by Inuit east of the Pfeffer River (Hall 1869: Diary 31). These were later identified as the remains of Lieutenant Henry Le Vesconte of HMS Erebus. The third individual was identified as Lieutenant John Irving of HMS Terror, whose partial remains were found near Victory Point by Schwatka in 1879. The identification of Irving's remains was based on the discovery in the grave of a medal awarded to him. Some doubts have been expressed about the identifications of both Peglar (for example Cyriax and Jones 1954) and Le Vesconte (Mays and others 2011).

The potential for new identifications of Franklin expedition sailors arose in August 2013, when remains from three members of the Franklin expedition were recovered from $\mathrm{NgLj}-3$, an archaeological site on the southern shore of Erebus Bay, King William Island (Stenton and others 2015). An important element of the multiple analyses now in progress is the possibility of identifying some of the remains from $\mathrm{NgLj}-3$, and from two nearby sites ( $\mathrm{NgLj}-1$ and $\mathrm{NgLj}-2)$. This is being undertaken principally through mtDNA analysis of 30 bone samples obtained from these sites, but the availability of two intact crania from $\mathrm{NgLj}-3$ provided an opportunity to explore an additional method through which to possibly identify those remains since photographs of some of the expedition's officers exist.

Facial reconstruction is an investigative tool that is often used in forensic contexts as a means of jogging peoples' memories in cases for which law enforcement personnel have no leads (see Prag and Neave 1997; Taylor 2001; and Wilkinson 2004 for general reviews). This method has also been applied to archaeological and historic remains with the goal of determining what an individual might have looked like in life, or supporting a tentative identification of an individual derived from other forms of other evidence (for example documents, skeletal features, associated artefacts). Archaeological examples of facial reconstructions include
Johann Sebastian Bach (His 1895), Kennewick Man (Chatters 2002), King Tut (National Geographic 2005) and a number of other Egyptian mummies (Cesarani and others 2004; Gill-Robinson and others 2006; Neave 1979; Wilkinson 2003, 2008), a young female from 5th century BCE Athens (Papagrigorakis and others 2011), the poet Dante (Benazzi and others 2009), Ferrante Gonzaga, an Italian Renaissance nobleman (Benazzi and others 2010), King Richard III (National Geographic 2013), and another crewmember of the 1845 Franklin expedition who in 1872 had been identified as Lieutenant Henry Le Vesconte. In the latter example, the facial reconstruction, when combined with the results of new analyses, suggested that the remains were not those of Le Vesconte but possibly those of Harry D. S. Goodsir, an assistant surgeon on the expedition (Mays and others 2011).

\section{NgLj-3 skeletal assemblage}

$\mathrm{NgLj}-3$ is an archaeological site on the south shore Erebus Bay, on southwest King William Island, Nunavut. In 1993 human bones including two crania were found on the site's surface in direct association with artefacts derived from the 1845 Franklin expedition. These are thought to be the remains of two individuals first discovered at the location in 1859 by McClintock (McClintock 1860: 265-266) and rediscovered and buried in 1879 by the Schwatka search expedition (Stackpole 1965: 8889). The disturbed condition of the burial feature in 1993 appeared to indicate that its contents had been scattered and, presumably, lost many years earlier. Included among the remains, however, was a third cranium found deeply embedded in the ground surface, suggesting that other bones might still be present below the surface. In 2013, the cranium was excavated and beneath it 76 additional human bones were found, representing a minimum of three individuals (Stenton and others 2015).

\section{Descriptions of the crania}

Of the three crania recovered from $\mathrm{NgLj}-3$ two were sufficiently intact to allow craniofacial reconstruction. One (\#80) was found on the surface of $\mathrm{NgLj}-3$, and the second (\#35) was found within the buried deposit. Cranium \#80 was intact and exhibited bleaching, weathering, and lichen growth on its ectocranial surface, reflecting longterm exposure to the elements. Some postmortem damage had occurred to the right maxilla. The left second maxillary molar was present, the right first molar had been lost antemortem, and the remaining 14 maxillary teeth had been lost postmortem. Cranium \#35 was remarkably well preserved, with all bones intact and in excellent condition. Seven teeth were present in the maxilla; the remaining teeth had been lost postmortem. A mandible found in the same deposit (\#34), although similar in appearance to cranium \#35, was found to articulate with cranium \#80. It was in excellent condition and contained six teeth, the remainder having been lost postmortem. 


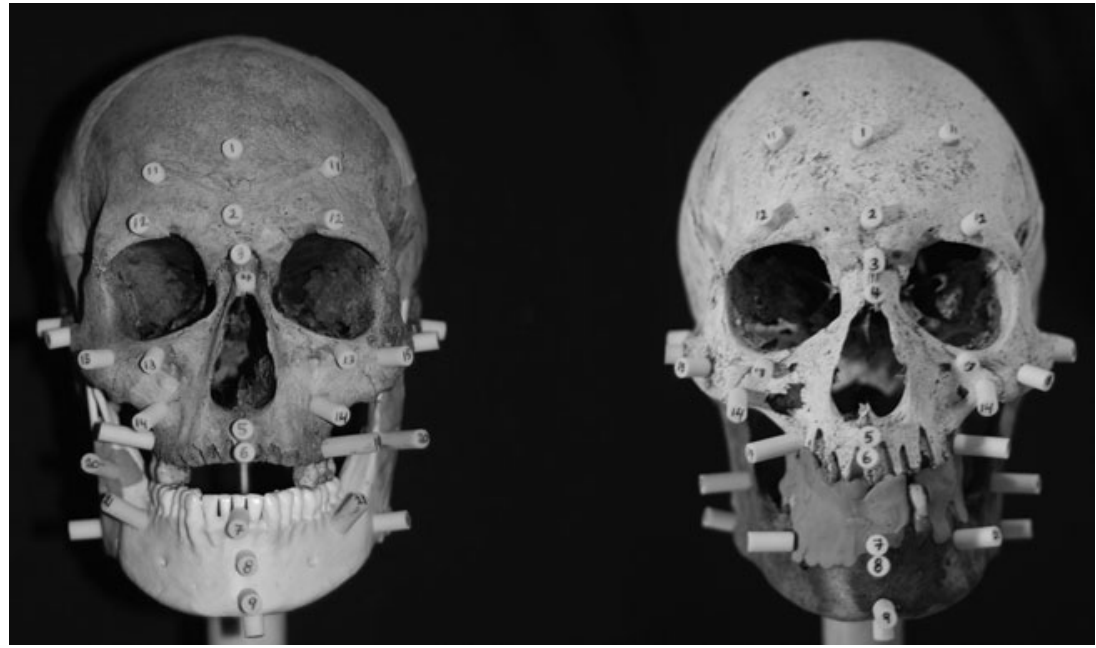

Fig. 1. Frontal views of Cranium \#35 (left) and Cranium \#80 (right) mounted for reconstruction.

Both crania exhibited features characteristic of males, including large supraorbital ridges, blunt supraorbital margins, large mastoid processes, and, in the case of cranium \#80, a moderately pronounced occipital protuberance (Buikstra and Ubelaker 1994). Discriminant function analysis using the discriminant functions developed by Giles (1970) for Caucasians, confirmed both to be male. Application of the ectocranial suture closure method of age estimation (Meindl and Lovejoy 1985) yielded composite scores of 0 and 1 for the vault and lateral-anterior sutures of cranium \#35 respectively, and 14 and 5 for the vault and lateral-anterior sutures of cranium \#80 respectively. These scores indicate age estimates of 21 to 42 years (mean $=32$ ) for the first individual, and 28 to 52 years $($ mean $=41.1)$ for the second.

The majority of morphological features of cranium \#35 indicate that this individual was of European ancestry (Byers 2011). Similarly, discriminant function analysis (Giles and Elliot 1962) revealed that it falls within the Caucasian range for both sets of functions. The majority of morphological features of cranium \#80 also point to this individual being of European ancestry. Discriminant function analysis (Giles and Elliot 1962) revealed that it falls within the African-American range for the first set of functions and the Caucasian range for the second set.

\section{Facial reconstructions}

Complete two- and three-dimensional facial reconstructions were conducted on the two crania by one of the authors (DT). The facial reconstructions followed the 'American Method' developed by Gatliff in 1967 (Taylor 2001), which involves the placement on anatomical landmarks of tissue depth markers cut for length for an average tissue depth (normal male who is neither slender nor obese) (Rhine and Moore 1984). Tissue was reconstructed using oil-based clay layered according to depth markers and then smoothed and sculpted.
Both crania were mounted on a custom handmade stand that rested on a turntable (Fig. 1). In the case of cranium \#80, removable tape was used to protect fragile areas and small gaps on the skull prior to the reconstruction. As only seven maxillary teeth remained in cranium \#35 and only one in cranium \#80, clay was used to fill in the missing teeth, and the mouth of each individual was reconstructed in a closed position.

The crania and mandibles were connected in a normal resting position. As cranium \#35 was missing its mandible, a mandible from an individual of European descent was substituted. This mandible was carefully aligned with the skull using the teeth and landmarks on the cranium, and it was connected to the skull using oilbased clay and wooden sticks to ensure its stability. It is recognised that replacing a missing mandible with a substitute can lead to errors in a facial reconstruction. A study by Colledge (1996), for example, found that in cases where parts of a skull such as the frontal bone, maxilla, zygomatic bones, and mandible are missing, these areas can be remodelled with reasonable accuracy, with the exception of the mandible. Errors in the reconstruction of the chin height and jaw line, in particular, can have a detrimental effect on the accuracy of the facial reconstruction produced (Colledge 1996, cited in Wilkinson 2004: 162). Nevertheless, facial recognition has been found to be more successful when a face is viewed in its entirety (Taylor 2001), and the reconstruction of a mandible in cases where it is missing has been done utilising a variety of techniques, including taking frontal and lateral radiographs to reconstruct cranio-facial relationships (Sassouni 1957; Taylor 2001: 337), and using virtual modelling (Benazzi and others 2009). It is also important to stress that a facial reconstruction is meant to provide only an approximation of what an individual may have looked like in life, and is not a method of positive identification. Analyses of dental records, DNA, and/or other accepted methods 


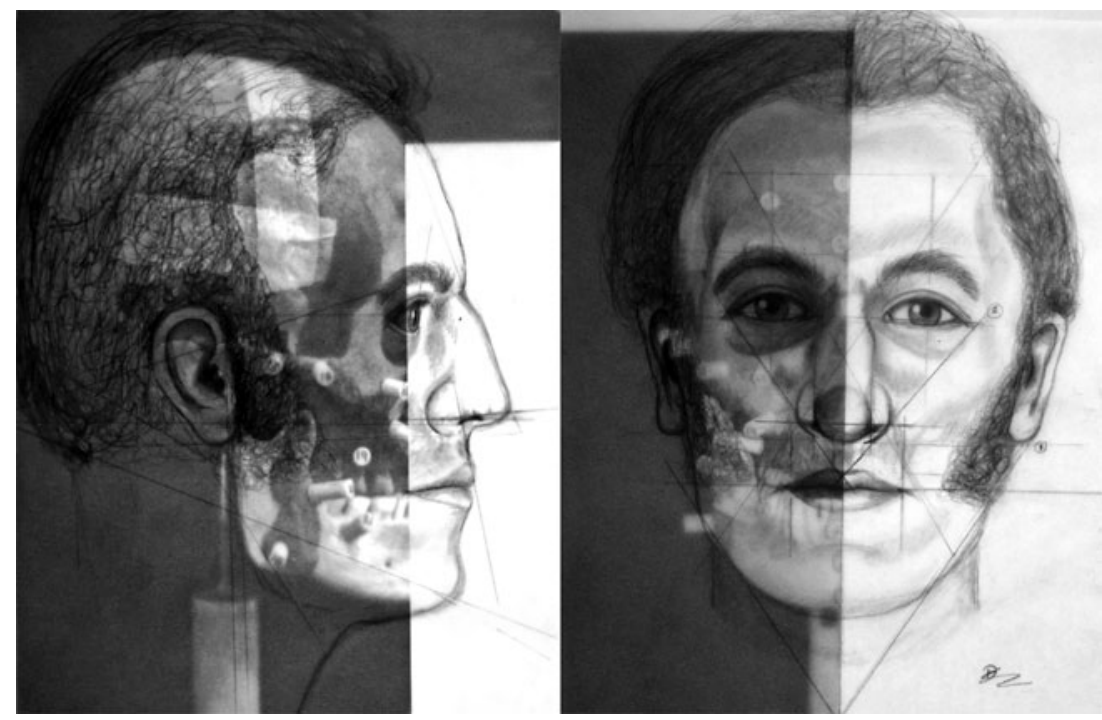

Fig. 2. Two-dimensional lateral and frontal reconstructions of Cranium \#35.

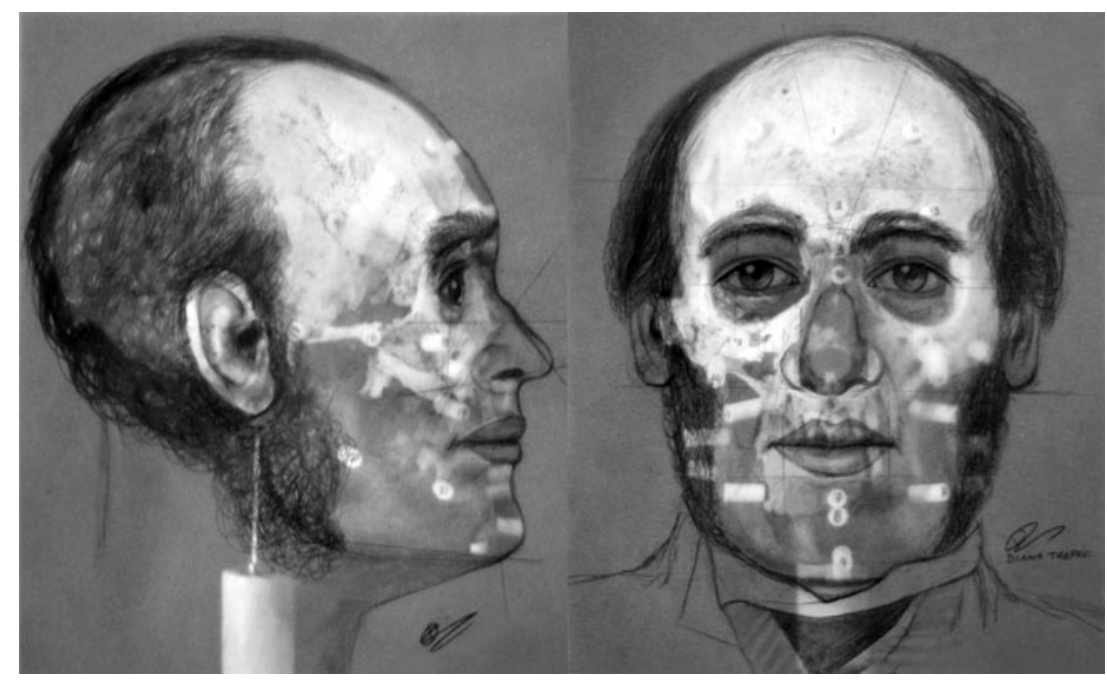

Fig. 3. Two-dimensional lateral and frontal reconstructions of Cranium \#80.

are required to make such an identification in these cases.

Two-dimensional lateral and frontal reconstructions of the crania are shown in Figs. 2 and 3. The vertical distance of the mouth was determined by measuring the distance from the cemento-enamel junction (CEJ) of the central maxillary incisors to the CEJ of the central mandibular incisors (Taylor 2001). The width of the mouth was established by measuring the width of the six anterior teeth as indicated by their sockets. The width of the nose was determined by measuring the maximum width of the nasal aperture. The anterior nasal spine was used as a guide for the angle of projection of the nose, and a line drawn from the anterior nasal spine to the nasal bones defined the shape of the nose. Generic ears were created and placed on the crania so that the external auditory canal lines were aligned with the external acoustic meatus in each. To finish the face, the clay was smoothed to simulate the outer layer of skin, and dental and sculpting tools were used to add details. Eyebrows were sculpted following the brow ridges on the crania, and facial hair was added in the style common for the era. High quality medical grade acrylic prosthetic eyes were placed in the orbits, and both reconstructions were given clothing reflective of the temporal and cultural context of the specimens.

\section{Discussion}

Each cranium exhibited distinct features that are reflected in its reconstruction. Cranium \#35 (Fig. 4) is marked by projecting nasal bones and a pronounced nose with a large, bulbous tip. Other features evident in the reconstruction include deep-set eyes, a brow shape that follows the brow line, and high cheekbones. Cranium $\# 80$, in contrast, had an asymmetrical nasal aperture and very narrow and asymmetrical nasal bones (Fig. 5). Consequently, the bridge of the nose appears pinched in the 


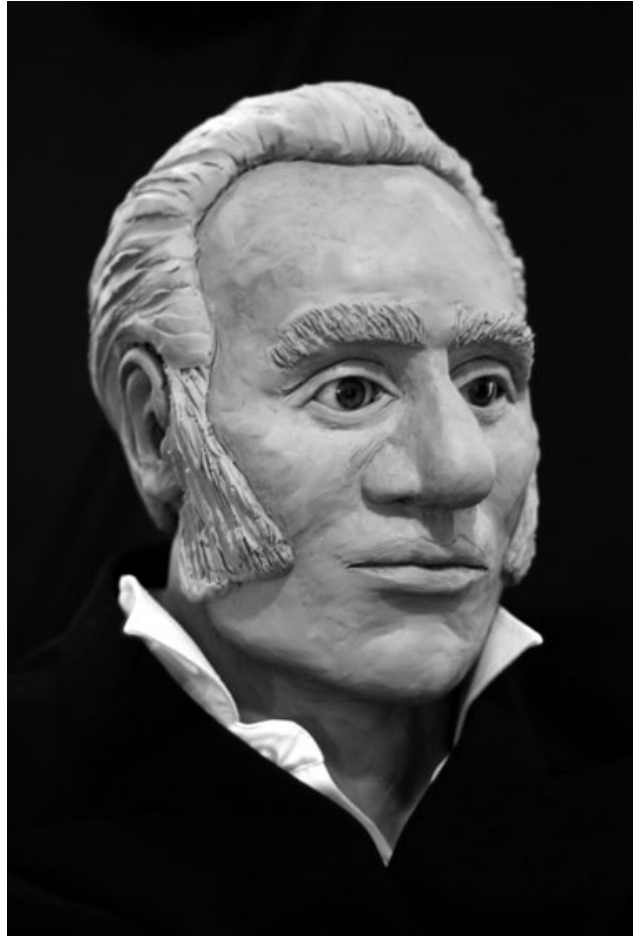

Fig. 4. Three-dimensional reconstruction of Cranium \#35.

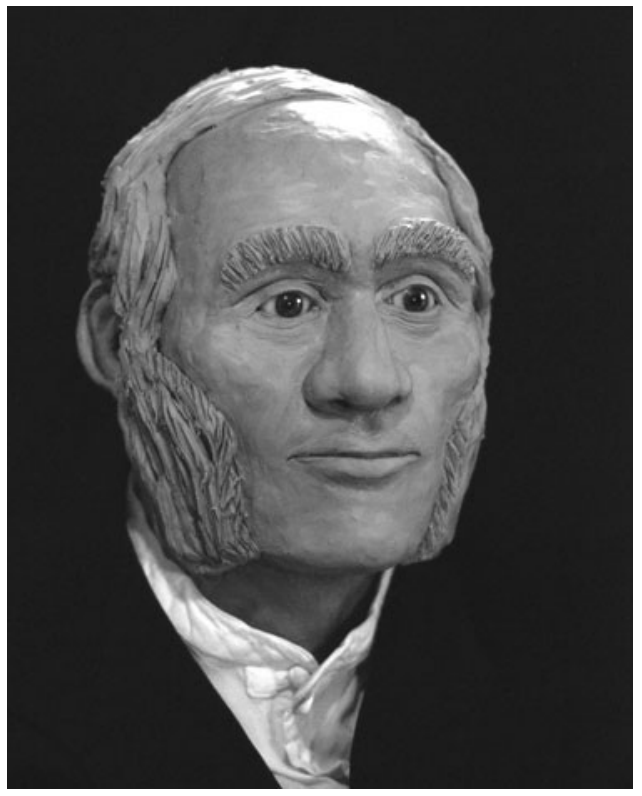

Fig. 5. Three-dimensional reconstruction of Cranium \#80.

reconstruction. This individual also had a broad jaw and high cheekbones, and a uniquely shaped forehead that was rounded at the sides and had a slanted appearance in the middle.

Few images of the members of the Franklin expedition are available for comparison, the best known being daguerreotype portraits taken of 14 of the 24 senior officers of HMS Erebus and HMS Terror on the eve of the expedition's departure. Hobson conjectured that the skeleton of the individual he found in the stern of the boat at NgLj-3 was an officer (Stenton 2014: 518), which raises the possibility that one of the two crania belongs to one of those 14 senior officers. Comparisons with the daguerreotypes revealed similarities between the reconstructions and two of the officers. For example, the reconstruction of cranium \#35 bears some resemblance to the photograph of Lieutenant Graham Gore, and the reconstruction of cranium \#80 and mandible \#34 bears a resemblance to James Reid, ice master on HMS Erebus. It is not suggested, however, that the remains from $\mathrm{NgLj}-3$ are those of either man. As previously noted, it is known from the Victory Point cairn record that Lieutenant Gore had died prior to the start of the retreat to the Back River; thus his remains cannot plausibly have been recovered from Erebus Bay, some $70 \mathrm{~km}$ south of Victory Point. Cranium \#35 must, therefore belong to another crewmember. Similarly, the conclusive identification of cranium \#80 and mandible \#34 as belonging to James Reid is not possible because while facial reconstruction can be used to exclude individuals, it cannot confirm identification with $100 \%$ certainty.

The eventual identification of these remains might, however, be determined through other sources of information. A separate study of a suite of DNA samples obtained from $\mathrm{NgLj}-3$ and other Franklin sites is underway which includes samples from both crania and the mandible. Comparison of the DNA results with samples obtained from living descendants of members of the Franklin expedition could lead to the identification of one or more of the men who died at Erebus Bay which, in turn, might shed new light on the events that followed the abandonment of the HMS Erebus and HMS Terror on 22 April 1848.

\section{Acknowledgements}

We wish to thank the Inuit Heritage Trust for its support of the recovery and analysis of the human remains from $\mathrm{NgLj}-3$. Thanks are also extended to three anonymous reviewers for their helpful comments on an earlier draft of the paper. This research was funded by the Government of Nunavut Department of Culture and Heritage, Nunavut Archaeology Program.

\section{References}

Beattie, O. and J.G. Geiger. 1987. Frozen in time: unlocking the secrets of the Franklin expedition. Saskatoon: Western Producer Prairie Books.

Benazzi, S., M. Fantini, F. De Crescenzio, G. Mallegni, F. Mallegni, F. Persiani, G. Gruppioni. 2009. The face of the poet Dante Alighieri reconstructed by virtual modelling and forensic anthropology techniques. Journal of Archaeological Science 36: 278-283.

Benazzi, S., P. Bertelli, B. Lippi, E. Bedini, R. Caudana, G. Gruppioni, F. Mallegni. 2010. Virtual anthropology and forensic arts: the facial reconstruction of Ferrante Gonzaga. Journal of Archaeological Science 37: 1572-1578. 
Buikstra, J.E. and D.H. Ubelaker. 1994. Standards for data collection from human skeletal remains. Fayetteville, AR: Arkansas Archeological Survey (Research series 44).

Byers, S.N. 2011. Introduction to forensic anthropology. 4th Edn. New York: Pearson.

Cesarani, F., M.C. Martina, R. Grilletto, R. Boano, A.M. Donadoni Roveri, V. Capussotto, A. Giuliano, M. Celia, G. Gandini. 2004. Facial reconstruction of a wrapped Egyptian mummy using MDCT. American Journal of Roentgenology 183: 755758.

Chatters, J.C. 2002. Ancient encounters: Kennewick Man and the first Americans. New York: Simon and Schuster.

Colledge, H. 1996. Loss of face? The effect on the outcome of craniofacial reconstruction when part of the skull is missing. Unpublished M.Sc. dissertation. Manchester: University of Manchester.

Cyriax, R.J. 1939. Sir John Franklin's last Arctic expedition. London: Methuen and Co. Ltd.

Cyriax, R.J., and A.G.E. Jones. 1954. The papers in the possession of Harry Peglar, captain of the foretop, H.M.S. Terror 1845. The Mariner's Mirror 40:186-195.

Gilder, W.H. 1881. Schwatka's search. Sledging in the Arctic in quest of the Franklin records. New York: Charles Scribner's Sons.

Giles, E. 1970. Discriminant function sexing of the human skeleton. In: Stewart, T.D. (editor). Personal identification in mass disasters. Washington DC: Smithsonian Institution, National Museum of Natural History: 99-109.

Giles, E. and O. Elliot. 1962. Race identification from crania measurements. Journal of Forensic Sciences 7: 147-157.

Gill-Robinson, H., J. Elias, F. Bender, T.T. Allard, R.D. Hoppa. 2006. Using image analysis software to create a physical skull model for the facial reconstruction of a wrapped Akhmimic Mummy. Journal of Computing and Information Technology 14: 45-51.

Hall, C.F. 1869. Charles Francis Hall collection, 1858-1871. Washington D.C.: Archives Center, National Museum of American History.

His, W. 1895. Johann Sebastian Bach. Forshungen uber dessen Brabstatte, Bebeine und Antlitz. Bericht an den Rath der Stadt Leipzig. Leipzig: FCW Vogel.

Hobson, W.R. 1859. Report of sledge journey, April-June 1859; Lieut. Wm. Hobson. In: M'Clintock, F.L. Arctic expeditions 1848-1859. Ottawa: Library and Archives Canada, MG 24 , H27 (Mfilm A-34).

Klutschak, H.W. 1987. Overland to Starvation Cove. With the Inuit in search of Franklin 1878-1880. (Editor W. Barr). Toronto: University of Toronto Press.

Mays, S., A. Ogden, J. Montgomery, S. Vincent, W. Battersby, G.M. Taylor. 2011. New light on the personal identification of a skeleton of a member of Sir John Franklin's last expedition to the Arctic, 1845. Journal of Archaeological Science 38(7): 1571-1582.
McClintock, F.L. 1860. The voyage of the 'Fox' in the Arctic seas: a narrative of the discovery of the fate of Sir John Franklin and his companions. Boston: Ticknor and Fields.

Meindl, R.S. and C.O. Lovejoy. 1985. Ectocranial suture closure: a revised method for the determination of skeletal age at death based on the lateral-anterior sutures. American Journal of Physical Anthropology 68: 57-66.

National Geographic. 2005. The new face of King Tut. URL: http:// news.nationalgeographic.com/news/2005/05/photogalleries/ tut_mummy/photo 8 .html.

National Geographic. 2013. The real Richard III. URL: http:// news.nationalgeographic.com/news/2013/13/130205richardiii-english-king-3d-reconstruction-sciencearchaeology/.

Neave, R.A.H. 1979. Reconstruction of the heads of three Egyptian mummies. Journal of Audiovisual Media in Medicine 2: 156-164.

Papagrigorakis, M.J., P.N. Synodinos, A. Antoniadis, E. Maravelakis, P. Toulas, O. Nilsson, E. Baziotopoulou-Valavani. 2011. Facial reconstruction of an 11-year-old female resident of 430 BC Athens. Angle Orthodontist 81: 171-179.

Prag, J. and R.A.H. Neave. 1997. Making faces. London: British Museum Press.

Rhine, J.S., and C.E. Moore. 1984. Facial reproduction: tables of facial tissue thicknesses of American caucasoids in forensic anthropology. Albuquerque NM: University of New Mexico, Maxwell Museum of Anthropology (Technical series 1).

Ross, W.G. 2002. The type and number of expeditions in the Franklin search 1847-1859. Arctic 55(1): 57-69.

Sassouni, V. 1957. Palatroprint, physioprint, and roentgenographic cephalometry as new methods in human identification. Journal of Forensic Sciences 2: 429-443.

Stackpole, E.A. (editor). 1965. The long Arctic search: the narrative of Lieutenant Frederick Schwatka, U.S.A, 1878-1880, seeking the records of the lost Franklin expedition. Mystic, Con: Maine Historical Association Inc.

Stenton, D.R. 2014. 'A most inhospitable coast': the report of Lieutenant William Hobson's 1859 search for the Franklin expedition on King William Island. Arctic 67(4): 511-522.

Stenton, D.R, A. Keenleyside, R.W. Park. 2015. The 'boat place' burial: new skeletal evidence from the 1845 Franklin expedition. Arctic 68(1): 32-44.

Taylor, K.T. 2001. Forensic art and Illustration. Boca Raton, Fl: CRC Press.

Wilkinson, C.M. 2003. The facial reconstruction of the marina El-Alamein mummy. Warsaw: Warsaw University (Polish Archaeology in the Mediterranean XIV Reports 2002): 6671.

Wilkinson, C.M. 2004. Forensic facial reconstruction. Cambridge: Cambridge University Press.

Wilkinson, C.M. 2008. The facial reconstruction of ancient Egyptians. In: David, R. (editor). Egyptian mummies and modern science. Cambridge: Cambridge University Press: 162-180. 